\title{
Nuclear Engineering Academic Programs Survey, 2003
}

\section{Survey Universe}

The survey includes degrees granted between September 1, 2002 and August 31, 2003. Thirty-three academic programs reported having nuclear engineering programs during the survey time period and all responded (100\% response rate). Three of the programs included in last year's report were discontinued or out-of-scope in 2003. One new program has been added to the list. This year the survey data include U.S. citizenship, gender, and race/ethnicity by degree level.

\section{Degree Data}

Bachelor's Degrees. The number of B.S. degrees granted in 2003 by nuclear engineering programs decreased from 2002. It should be noted that the three programs which were discontinued/out-of-scope after 2002 reported a total of 17 B.S. degrees in 2002. (See Table 1.) The number of degrees in 2003 was still substantially greater than the number of B.S. degrees granted in 2001 (which was the lowest number in over a decade). Nuclear engineering majors accounted for $86 \%$ of all B.S. degrees with the remaining $14 \%$ in nuclear engineering option programs. (See Table 2.)

Graduate Degrees. The number of masters' and doctorate degrees granted in 2003 both increased over 2002. (See Table 1.) The Ph.D. degrees increased by 16 percent. Nuclear engineering majors accounted for $98 \%$ of the M.S. degrees and all of the Ph.D. degrees. (See Table 2.)

Table 1. Nuclear Engineering Degrees, 1998-2003

\begin{tabular}{cccc} 
& \multicolumn{3}{c}{ Degrees } \\
\cline { 2 - 4 } Year & B.S. & M.S. & Ph.D. \\
\hline 2003 & 166 & 132 & 78 \\
2002 & $195^{*}$ & 130 & 67 \\
2001 & 120 & 145 & 80 \\
2000 & 159 & 133 & 74 \\
1999 & 199 & 142 & 86 \\
1998 & 222 & 160 & 98
\end{tabular}

*Three programs were discontinued/out-of-scope after 2002 and not included in the 2003 survey. These three programs reported a total of 17 B.S. degrees in 2002.

Table 2. Nuclear Engineering Degrees by Curriculum, 2003

\begin{tabular}{lccc} 
Curriculum & B.S. & M.S. & Ph.D. \\
\hline Nuclear Engineering Major & 142 & 129 & 78 \\
Nuclear Engineering Option & 24 & 3 & 0
\end{tabular}




\section{U.S. Citizenship, Gender, and Race/Ethnicity Data}

U.S. citizenship, gender, and race/ethnicity data were reported for all but 1 of the B.S. degree graduates. Among the B.S. degree graduates, 4 were reported as non-U.S. citizens; 35 of the 165 reported (21\%) were females; and of the 161 reported as U.S. citizens, 13 (8\%) were non-Caucasian. (See Table 3.)

Among 132 M.S. degree graduates, 33 (25\%) were non-U.S. citizens; 19 (14\%) were females; and of the 99 U.S. citizens, 17 (17\%) were non-Caucasian.

Among the Ph.D. degree graduates, 28 (36\%) were non-U.S. citizens; 10 (13\%) were female; and of the 50 reported as U.S. citizens, 9 (18\%) were non-Caucasian.

Table 3. U.S. Citizenship, Gender, and Race/Ethnicity Data, 2003

\begin{tabular}{|c|c|c|c|c|c|c|c|}
\hline & & $\begin{array}{l}\text { Asian/ } \\
\text { Pacific }\end{array}$ & & & & & \\
\hline $\begin{array}{c}\text { Non U.S. } \\
\text { Citizen }\end{array}$ & $\begin{array}{c}\text { African } \\
\text { American }\end{array}$ & $\begin{array}{c}\text { Islander } \\
\text { American }\end{array}$ & $\begin{array}{l}\text { Caucasian } \\
\text { American }\end{array}$ & $\begin{array}{l}\text { Hispanic } \\
\text { American }\end{array}$ & $\begin{array}{c}\text { Native } \\
\text { American }\end{array}$ & $\begin{array}{c}\text { Other } \\
\text { American }\end{array}$ & $\begin{array}{c}\text { Not } \\
\text { Reported }\end{array}$ \\
\hline
\end{tabular}

\section{B.S. degree} Female

Male

Not reported

3
1
0

M.S. degree

Female

Male

Not reported

$\begin{array}{cc}7 & 0 \\ 26 & 2 \\ 0 & 0\end{array}$

0
1
0

0
4
0

31
117
0

0
3
0

1
1
0

0

Ph.D. degree

\section{Female}

Male

Not reported

$\begin{array}{cc}4 & 0 \\ 24 & 1 \\ 0 & 0\end{array}$

$\begin{array}{cc}2 & 10 \\ 2 & 72 \\ 0 & 0\end{array}$

0
1
0

0
0
0

$\begin{array}{cc}0 & 0 \\ 10 & 0 \\ 0 & 0\end{array}$

ported

$\begin{array}{ll}1 & 4 \\ 4 & 37 \\ 0 & 0\end{array}$

$\begin{array}{cc}4 & 0 \\ 37 & 0 \\ 0 & 0\end{array}$

0
0
0

$\begin{array}{ll}1 & 0 \\ 2 & 0 \\ 0 & 0\end{array}$


Table 4. Nuclear Engineering Degrees by Academic Institution, 2003

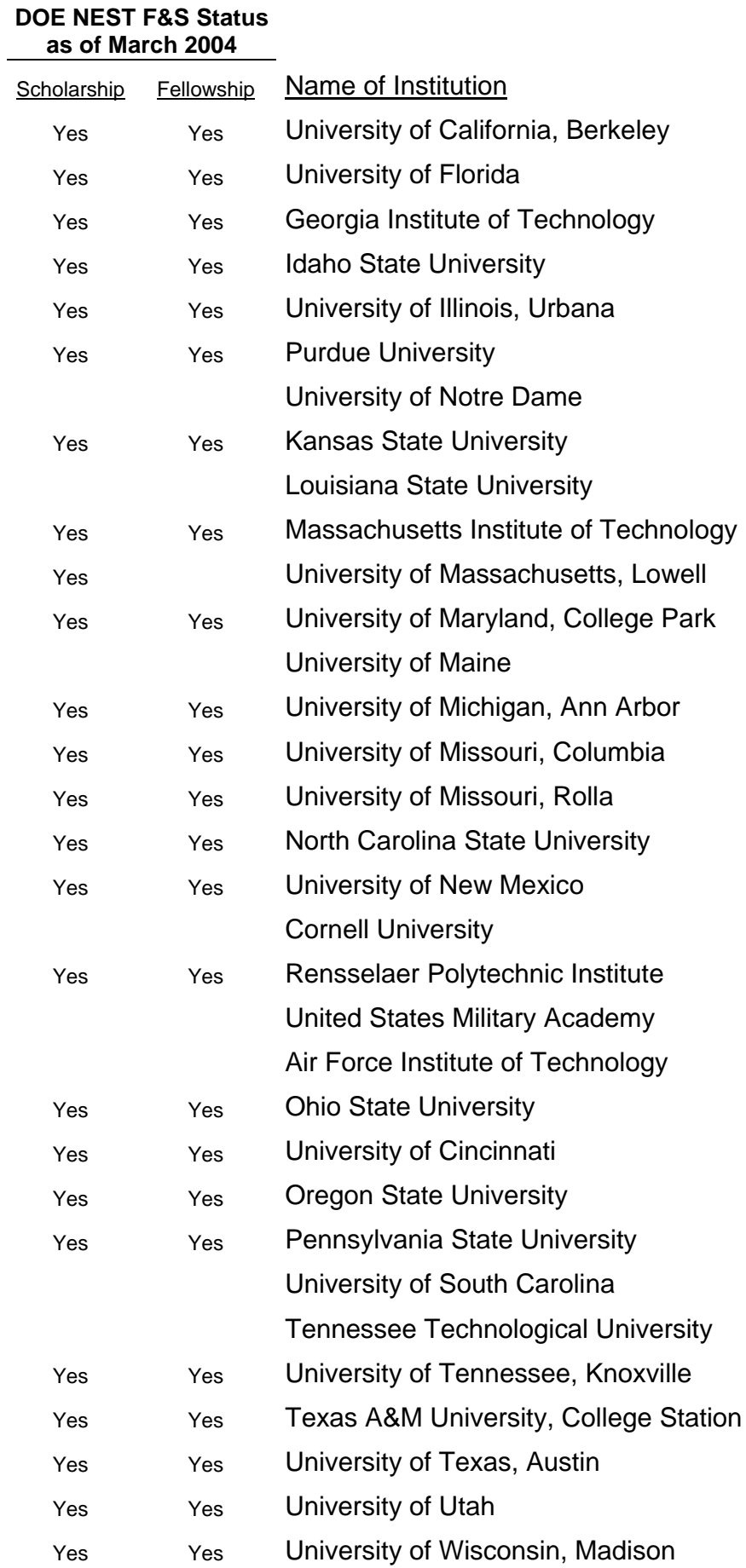

Totals 
Prepared by: Science and Engineering Education, Oak Ridge Institute for Science and Education, March 2004.

This document describes activities performed under contract number DE-AC05-000R22750 between the U.S. Department of Energy and Oak Ridge Associated Universities.

All opinions expressed in this report are the author's and do not necessarily reflect policies and view of the U.S. Department of Energy or the Oak Ridge Institute for Science and Education.

The Oak Ridge Institute for Science and Education (ORISE) is a U.S. Department of Energy facility focusing on scientific initiatives to research health risks from occupational hazards, assess environmental cleanup, respond to radiation medical emergencies, support national security and emergency preparedness, and educate the next generation of scientists. ORISE is managed by Oak Ridge Associated Universities. 